\title{
Insiders' Beliefs and Attitudes towards using Technology Assisted Language Teaching to Minimize FLA among Ethiopian University EFL Students
}

\author{
Berhane Gerencheal, Deepanjali Mishra, Ataklti Tesfay
}

\begin{abstract}
The study was conducted on 38 University EFL major students and on their 10 EFL teachers to examine their belief towards the role of using Technology Assisted Language Teaching (TALT-Hereafter) in minimizing students' FLA. The data were gathered using both qualitative and quantitative methods. The quantitative data was collected using by GBM and GAM (McCroskey \& Richmond, 1989) which are the most standardized and highly reliable data gathering tools to measure beliefs and attitudes of respondents in wide range topics. Three open ended questions were also used as data collecting instrument to reveal the practice of using TALT in the EFL classroom. Finally the descriptive analysis of the GBM result showed that both EFL students $(m=5.87 ; S D$ 0.567) and their teachers ( $m=4.85 ; S D=.672)$ had strong belief on the role of using TALT in minimizing FLA. The descriptive analysis of the GAM also revealed that both EFL students ( $m=6.04 ; S D$ 0.513) and their teachers $(m=4.3 ; S D=.572)$ had positive attitude towards using TALT during teaching-and-learning EFL. However, the qualitative data revealed that the actual practice in using technology assisted language teaching-and-learning trend was found very low and discouraging in both the EFL students and their teachers. Finally, the study ends with practical recommendations for the main actors to use TALT in EFL classes to make the classroom less stressful.
\end{abstract}

Keywords : Technology Assisted Language Teaching, Foreign Language Anxiety, English as a Foreign Language.

\section{INTRODUCTION}

Since long decades ago, technology has played an important role in the second/foreign language teaching and learning context. In many parts of the world, several foreign language classrooms has been assisted using different audio or/and audio-visual teaching aids to accelerate students in their FL learning. On the other hand, foreign language anxiety FLA is currently found as one of the most considerable affective variables which influence negatively the FL learning process(Horwitz, Horwitz, \& Cope, 1986)(Abay, 2009; Aida, 1994; Horwitz, Horwitz, \& Cope, 1986; MacIntyre \& Gardner, 1989; Price, 1988)

Revised Manuscript Received on July 22, 2019.

* Correspondence Author

Berhane Gerencheal, Ph.D Scholar at KIIT University, Senior Lecturer at Aksum University.

Deepanjali Mishra, Ph.D and Professor at KIIT University, India

Ataklti Tesfay, Senior Lecturer at Aksum University

To date, many research studies have been conducted using correlation studies between FLA and many independent variables such as language achievement, gender, age, study level, proficiency level, motivation, self-efficacy, and learning styles. When some of the associations of FLA with some of the variables (achievement, age, motivation, proficiency level, study major, and self-efficacy) are consistent, some others like gender, age, and study majors are inconsistent from place to place and study to study. And this is considered as a great success in the area of FLA, and the work of Horwitz and her associates has contributed a lot for this area by conceptualizing the concept of FLA as "situation-specific anxiety" and the composition of three inter-related performance anxieties (Communication Apprehension, Fear of Negative Evaluation, and Test Anxiety) for the first time, introducing new reliable standardized measuring tool, i.e, Foreign Language Anxiety Scale (FLCAS-hereafter) (Horwitz et al., 1986). And this seminal work makes the research findings around relationship among anxiety and achievement, fluency, or performance to be more stable and consistent. However, in the above mentioned variables there are still inconsistencies happened because anxiety is really context-based and highly influenced by culture (Argaman \& Abu-Rabia, 2002; Horwitz, 2016)

Apart from this, since the quantitative correlation studies on language anxiety and other variables especially achievements and performances are well documented, many scholars have been recommending researchers to focus anxiety research mainly on the causes of FLA and mechanisms to reduce FLA. Even though many teacher- and student-related anxiety reducing mechanisms are also suggested, less emphasis has been given to investigate the role of technology in minimizing FLA which is the focus of this study. Finally practical recommendations for target groups and researchers to guide further research were also suggested.

\section{STATEMENT OF THE PROBLEM}

Following the work of Horwitz et al. 1986, a large body of research findings consistently revealed that the impact of FLA on language learning and language achievement has been showed consistent negative correlation over various studies. Similarly, in the Ethiopian Context the negative consequence of FLA

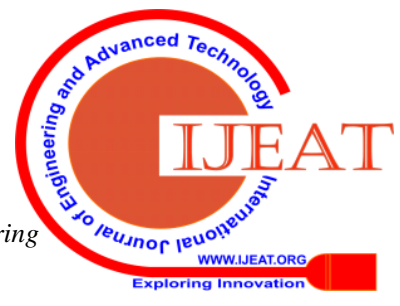


over secondary and tertiary levels EFL Students' achievement was reported(Abay, 2009; Gerencheal, 2016)

However, nowadays, most scholars and researchers in FLA suggest that current studies on FLA must focus on investigating mechanisms to reduce FLA to enjoy students relaxing FL classes since FLA is the most disturbing variable anxiety beyond the negative effect of it on language achievement (Horwitz, 2010; Tran, Baldauf, \& Moni, 2013). And many EFL students complain that the role of their most EFL teachers in the learning and teaching process is the main source of their language learning anxiety (Gerencheal, 2016; Horwitz et al., 1986; Tran et al., 2013). In Ethiopia, since most EFL teachers are local graduates who were also taught by local EFL teachers, their English proficiency is also very low(Gerencheal \& Mishra, 2019b; Kahsay, 2016). So, to cover their English command deficiency, most are observed to be harsh, authoritarian, dictator, or less friendly to their students. They also usually want to follow the traditional method of teaching where the teacher is considered as the active driver, but the students as a passive passenger. Students are usually not motivated to ask lots of questions freely to their teacher and/or to use technology in their EFL classes. Hence, as the researcher was teaching in Ethiopian universities for about ten years, he observed that students were very eager to use ICT-related audio-visual teaching aids in their EFL classes.

Therefore, as FL class is dominated by anxiety-provoking situations (Horwitz et al., 1986), Ethiopian higher education students could experience anxiety in English classes since highly advanced EFL learners experience anxiety while learning the language and particularly during speaking English (Woodrow, 2006). With this problem, many researchers and experts have suggested FLA reducing mechanisms, especially solutions related to the EFL teacher and the EFL students. However, attention is not given to using technology to reduce students' FLA. To narrow this gap, therefore, the central aim of this study was to investigate the belief of EFL students and their teachers towards using TALT in minimizing the EFL learners' FLA.

\section{REVIEW OF LITERATURE}

\section{Definition of FLA}

In broad terms, Brown defined anxiety as it is "associated with a feeling of uneasiness, frustration, self-doubt, apprehension, or worry"(Brown, 2000, p. 141). Spielberger (1966) also defines anxiety as a "subjective, consciously perceived feelings of apprehension and tension accompanied by or associated with activation or arousal of the automatic nervous system" According to Horwitz and her associates, FLA is also defined as "a distinct complex of self-perception, belief, feelings, and behaviors related to classroom language learning arising from the uniqueness of the language learning process"(Horwitz et al., 1986).

The above definition given by Horwitz et al. (1986) identified FLA as a type of situational specific psychological phenomenon bearing its own characteristics from language learning contexts. According to those authors, FLA is a relatively distinctive form of anxiety. Generally, Horwitz et al. (1986) were the pioneer to approach FLA as a separate phenomenon specific to a FL learning experience, and they have outlined the theoretical framework of FLA.

\section{Types of Anxiety}

Alpert and Haber 1960 cited in (Marcos-Llinás \& Garau, 2009) identify two types of anxiety: facilitative and debilitative. According to many researchers, facilitating anxiety is an increase in drive level and this helps to improve performance. Good example of facilitative anxiety could be students who are a risk taker as part of their language learning process; therefore, such kind of anxiety encourages the learners to learn more about the FL (Spielmann \& Radnofsky, 2001).

On the other hand, debilitative anxiety impedes language learning. Students who usually suffer from debilitative anxiety most likely experience to the feeling of fear or insecurity and also suffer from poor achievement and performance, and they need to abstain from the FL classes (Aida, 1994).

\section{Suggestions to Reduce Language Anxiety}

Several studies have suggested much helpful advice on how language anxiety could be minimized. In this section, however, we will see some prominent suggestions for reducing FLA, which is also believed to be important in the Ethiopian context.

In their seminal article, Horwitz and her associates have suggested for educators two options when dealing with anxious students: "(1) they can help them learn to cope with the existing anxiety-provoking situation, or (2) they can make the learning context less stressful" (Horwitz et al., 1986, p. 131). In other words, students' FLA levels can be reduced by focusing on the learners' characteristics that are resulting in the anxiety and by focusing on what we do as FL teachers and what goes on inside the classroom.

Since, in the Ethiopian context, English language anxiety has been found as the most obstacle in EFL learning (Abay, 2009; Gerencheal, 2016; Kassahun, 1996), using technology might have positive contribution in minimizing this problem. In relation to this, using technology assisted language teaching aids in the classroom are currently found more useful for many reasons. One thing technology assisted language teaching aids are entertaining, relaxing for EFL learners. They also offer wide range possibilities of language inputs customized to the student natures and needs. They can also be served as an authentic teaching material for EFL students who are far from the direct exposure of the native language speakers. Hence, we could make our EFL classes less stressful. And this environment could enhance language learning, and minimize language anxiety among foreign language learners.

\section{Technology in the Classroom}

Nowadays, in developed nations, there are many schools in which ICT is recognized as an instructional tool. The use of technology could make EFL classrooms more meaningful and interesting context for language learning. It can motivate EFL students and engages them in the language skills: speaking, reading, listening and writing easier (Genc Ilter, 2009). However, this does not mean only technology is sufficient for EFL classes, but EFL teachers should be fluent enough in English skills and

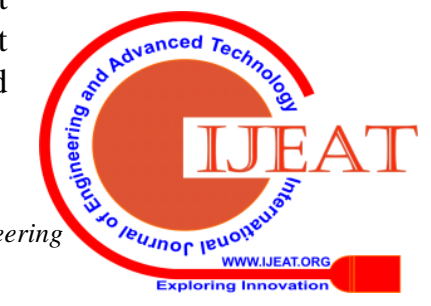


useful instructional strategies, and who can give learners engaging learning experiences to grow and to have more experiences to relate to their prior knowledge are required (Schwartz \& Pollishuke, 2012)

\section{Technology Assisted Language Teaching}

Nowadays, technology has contributed a lot to language teaching-and-learning. To get maximum advantage from technology, learners and teachers should be made familiar with technology-enhanced language instruction such as CALL (Computer Assisted Language Learning), CELL (Computer Enhanced Language Learning), and TELL (Technology Enhanced Language Learning). Even though technology is the key to Computer Assisted Language Learning, the role of EFL teacher in creating a whole learning environment system with his or her students is indispensable(Egbert, 2005) This idea is to mean that the technology cannot substitute for an EFL teacher; it should be considered as a support for language teaching-and-learning process. In the classroom, students should also be engaged in the authentic learning settings.

According to Egbert, to ensure greater success in language classes, students should get the following conditions: empowering students, making students to take an active role in the process, making them to receive continuous comprehensible input in the target language, exposing them to multiple instructional media, and varied input and feedback sources(Anderson \& Speck, 2001; Egbert, 2005; Li, 2005)

The basic research questions of this study were:

1. What is the awareness of EFL students and their teachers in the benefit of Technology based language teaching in minimizing FLA?

2. What is the attitude of EFL teachers and students towards using TALT in their language classroom?

What is the actual practice of EFL teachers in utilizing ICT in their teaching profession?

\section{METHODOLOGY OF THE STUDY}

\section{Research Design}

The present study used a mixed method approach particularly sequential mixed design, which consists of both quantitative and then qualitative modes of data gathering and analysis with quantitative at the initial.

\section{Study Area}

The study was Aksum University (AkU- hereafter) which is found at Ethiopia, Africa. Among the 20 or more operational public universities which have the department of English Language and Literature, AkU is one. And, the study area was randomly chosen among the abovementioned Universities. The university is particularly situated in the Northern part of the country at Tigray Regional State. This University is established by the government with very few departments which is English Language and Literature one among them. Since then, this department has been offered trainings mainly undergraduate trainings without interruption.

\section{Participants of the Study}

Only year II English language and Literature major students $(n=38 ; m=24, f=14)$ who was enrolled in 2017/18 at the above mentioned university were participated in this study. Ten EFL teachers who had taught EFL students since their admission to the university were also involved in the study.

\section{Method of Data Collections}

The researcher used background revealing questionnaire for both the EFL students and their EFL teachers. Quantitative data was collected using General Belief Measure (hereafter-GBM) and Generalized Attitude Measure (hereafter-GAM) that were developed by (McCroskey \& Richmond, 1989). GBM was used to examine the awareness of the students and their teachers on the benefit of ICT on minimizing students' FLA whereas GAM was used to investigate the attitude of the participants towards using ICT in classroom. Those two scales (GBM and GAM) were the most standardized bipolar scales to measure the belief and attitude of respondents on various areas with higher internal consistency as measured by Cronbach alpha. Accordingly, in this study they were found highly reliable i.e., Cronbach alpha 0.94 for the GBM, and 0.91 for the GAM. At last but not least, three open ended questions were also included in the questionnaire to the participants to check the practice of using TALT in the teaching-and-learning process.

\section{Method of Data Analysis:}

Only 34 valid questionnaires from the students and 10 questionnaires from the EFL teachers were found eligible for the quantitative analyses. Four students' questionnaires were discarded since they were found incomplete. After the quantitative data had been collected, basic descriptive statistics were performed using SPSS (Version 20) to respond the above stated research questions.

In the GBM, there are five bipolar adjective pairs with seven options to each of them. Before analysing the data, the responses to items 1, 4 and 5 were reversed and recoded so that higher mean scores (more than 4) always show a stronger agreement with the statement or a stronger belief on the role of using technology assisted language teaching in minimizing English language anxiety in learning EFL. On the contrary, lower mean scores (below 4) always indicate a stronger disagreement with the statement or a stronger disbelief on the role of using technology assisted language teaching in minimizing English language anxiety in learning EFL. Similarly, the total range of scores is 5-35 with scores above 20 signifying a stronger belief on the role of technology assisted language teaching in minimizing English language anxiety in learning EFL, and scores below 20 signifying a stronger disbelief on the role of technology assisted language teaching in minimizing English language anxiety in learning EFL. The total score of each participant was calculated by adding up the scores in all five items, and by dividing to the total number of items (i.e., 5), the mean of the scale can be calculated. The mean scores of the whole student sample and teacher 
sample would reveal the general belief of the students and the teachers, respectively.

In the GAM, there are six bipolar adjective pairs with seven options to each of them. This tool was basically used to measure the EFL teachers' and EFL students' attitude towards using TALT in EFL classes. Before going to analysis, the responses to items 2, 3, and 6 were reversed. Higher scores $(>4)$ always indicate more positive judgment on attitudes towards using TALT in EFL classes. On the contrary, lower scores $(<4)$ shows more negative judgment on attitudes towards using TALT in EFL classes. The total score of each participant was found by adding up the scores in all six items. The mean score of the EFL students and EFL teachers would reveal their general attitude towards using TALT in EFL classes.

Only 15 students' eight teachers' responses to the open-ended three items in the questionnaire were considered in the qualitative analyses. Others were discarded since students did not complete the questions properly.

\section{ANALYSIS AND DISCUSSIONS}

Table 1: Students' and Teachers' Awareness on the Benefit of Using TALT in Minimizing FLA as measure by GBM

\begin{tabular}{|l|l|l|l|l|l|}
\hline Using TALT is useful in minimizing FLA in EFL & \multicolumn{2}{l|}{ EFL teachers } & \multicolumn{2}{l|}{ EFL Students } \\
\cline { 2 - 5 } learning classes & Mean & SD & Mean & SD \\
\hline Agree ..............Disagree & 4.26 & .791 & 6.21 & .760 \\
\hline False...............True & 4.91 & .821 & 5.90 & .791 \\
\hline Incorrect............Correct & 5.01 & .802 & 5.58 & .725 \\
\hline Right...............Wrong & 4.98 & .821 & 5.89 & .787 \\
\hline Yes...................No & 5.10 & .811 & 5.78 & .844 \\
\hline Overall mean & $\mathbf{4 . 8 5}$ & $\mathbf{. 6 7 2}$ & $\mathbf{5 . 8 7}$ & $\mathbf{. 5 6 7}$ \\
\hline
\end{tabular}

In the above table 4.1 , the mean score of both the EFL teachers and their EFL students were found $>4.00$. This result shows that both the teachers and students were aware of the usefulness of TALT in minimizing FLA in their EFL classes since GBM mean > 4 indicates stronger agreement with the statement. However, in all the five-items of the
GBM, the overall students' mean score was higher (GBM $\mathrm{m}=5.87, \mathrm{SD}=.567)$ than to their teachers (GBM $\mathrm{m}=4.85$, $\mathrm{SD}=.672$ ). So, it could be said that the students might have been more aware on the role of TALT in minimizing FLA in EFL classes than their teachers might have.

Table 2: Students' and Teachers' Attitude towards Using TALT in EFL Classes as Measured by GAM

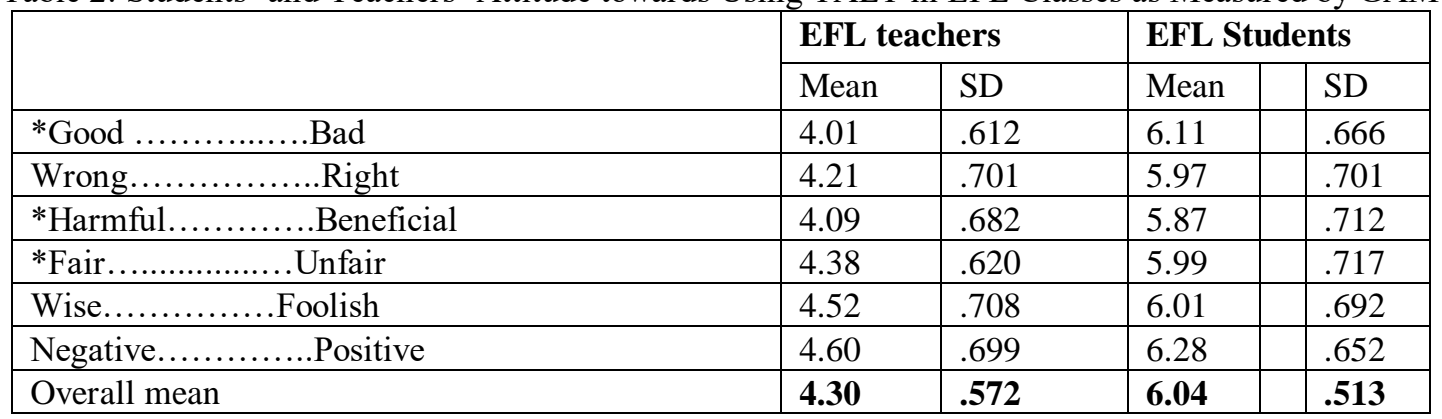

In the above table 4.2 , the mean score of both the EFL teachers and their EFL students to the GAM were also found $>4.00$. This result indicates that both the EFL teachers and their students had positive judgment on attitudes towards using TALT in EFL classes as long as GAM mean > 4 indicates the positive judgment towards the statement. However, in all the six-items of the GAM, the overall students' mean score was higher $(\mathrm{GAM} \mathrm{m}=6.04, \mathrm{SD}=.513)$ than their teachers (GAM m=4.3, SD=.572). So, it might be said that the EFL students had more positive judgment on attitude towards using TALT in EFL classes than their teachers could have.

Despite the findings related to the beliefs and the attitudes of EFL students and their teachers mentioned above, both the student' and teachers' practice of using TALT in their learning-and-teaching the language was found poor. Almost all the respondents mentioned that they did not regularly and deliberately use technology to support the teaching-and-learning of the EFL class.
In the Ethiopian EFL classes, studies confirmed that most of the students are suffering from moderate to high degree of FLA(Abay, 2009; Gerencheal, 2016; Gerencheal \& Mishra, 2019b, 2019a) Recently, for instance, Gerencheal and Mishra (2019a) reported that $83.5 \%$ of Ethiopia University EFL students were suffering from moderate to high degree of English language anxiety. This shows that FLA is the most critical variable in affecting English language learning among many Ethiopian students negatively. And in this study, both EFL teachers and their students had strong belief on the usefulness of TALT in minimizing the EFL students' English language anxiety despite their actual practice.

\section{CONCLUSION}

It is obvious that technology assisted language teaching plays a key role in making foreign language teaching and learning processes relaxing, effective, and effortless. FLA has been found to be one of the best predictors of success in foreign language learning by 
turning EFL students into more apprehensive, dreadful and forgetful. However, very less attention has been given to the role of technology on minimizing FLA which was the key aim of this study.

And nowadays, TALT is being recommended by many researchers and educational experts for many reasons, but language researchers in the area of FLA do not give due attention to it as lowering mechanism. However to practice this new innovative way of language teaching, at least the attitude of the major actors in the education sector (mainly the students and the teachers) should be positive. With regard to this, in this study, the attitude of both the EFL teachers and their students towards using TALT as measured by GAM was found very positive and encouraging even though the EFL teachers were comparatively found less positive than their students. So, concerned stakeholders should fulfill the technology as an important facility to enhance the EFL students' proficiency and to reduce their FLA. However, since FLA is a complex phenomenon, this could be one among the many possible solutions which might be considered in the EFL classrooms.

\section{REFERENCES}

1. Abay, N. (2009). English Language Classroom Anxiety: The Case of High and Low Achievers in Shire Preparatory School (Unpublished MA Thesis). Addis Ababa University, Addis Ababa.

2. Aida, Y. (1994). Examination of Horwitz, Horwitz, and Cope's Construct of Foreign Language Anxiety: The Case of Students of Japanese. The Modern Language Journal, 78(2), 155.

3. Anderson, R. S., \& Speck, B. W. (2001). Using Technology in K-8 Literacy Classrooms. Education Review//Reseñas Educativas.

4. Argaman, O., \& Abu-Rabia, S. (2002). The Influence of Language Anxiety on English Reading and Writing Tasks Among Native Hebrew Speakers. Language, Culture and Curriculum, 15(2), 143-160.

5. Brown, H. D. (2000). Principles of language learning and teaching

6. Egbert, J. (2005). CALL essentials: Principles and practice in CALL classrooms. Teachers of English to Speakers of Other Languages Alexandria, VA.

7. Genc Ilter, B. (2009). Effect of technology on motivation in EFL classrooms. Online Submission, 10(4).

8. Gerencheal, B. (2016). Gender Differences in Foreign Language Anxiety at an Ethiopian University: Mizan-Tepi University Third Year English Major Students in Focus. 1(1), 1-16.

9. Gerencheal, B., \& Mishra, D. (2019a). Foreign Language Anxiety among Ethiopian University EFL Students. Online Submission, 8, 43-48.

10. Gerencheal, B., \& Mishra, D. (2019b). Foreign Languages in Ethiopia: History and Current Status. Online Submission, 6(1), 1431-1439.

11. Horwitz, E. K. (2010). Foreign and second language anxiety. Language Teaching, 43(2), 154-167.

12. Horwitz, E. K. (2016). Factor Structure of the Foreign Language Classroom Anxiety Scale: Comment on Park (2014). Psychological Reports, 119(1), 71-76.

13. Horwitz, E. K., Horwitz, M. B., \& Cope, J. (1986). Foreign Language Classroom Anxiety. The Modern Language Journal, 70(2), 125.

14. Kahsay, T. (2016). Proposed Language Reform for Ethiopia.

15. Kassahun, A. (1996). English Classroom Anxiety, Performance on Classroom Tasks and in Tests (Unpublished MA Thesis). Addis Ababa University, Ethiopia.

16. Li, W. (2005). The advantages of using technology in second language education. TH E Joural, 32(10), 38-42.

17. MacIntyre, P. D., \& Gardner, R. C. (1989). Anxiety and Second-Language Learning: Toward a Theoretical Clarification*. Language Learning, 39(2), 251-275.

18. Marcos-Llinás, M., \& Garau, M. J. (2009). Effects of Language Anxiety on Three Proficiency-Level Courses of Spanish as a Foreign Language. Foreign Language Annals, 42(1), 94-111.

19. McCroskey, J. C., \& Richmond, V. P. (1989). Bipolar Scales. In Measurement of Communication Behavior (pp. 154-167).

20. Price, M. L. (1988). Anxiety and the foreign language learner: Correlates of foreign language anxiety ( $\mathrm{PhD}$ Thesis). University of Texas at Austin.

21. Schwartz, S., \& Pollishuke, M. (2012). Creating the dynamic classroom: A handbook for teachers. Pearson Education Canada.
22. Spielmann, G., \& Radnofsky, M. L. (2001). Learning language under tension: New directions from a qualitative study. The Modern Language Journal, 85(2), 259-278.

23. Tran, T. T. T., Baldauf, R. B., \& Moni, K. (2013). Foreign Language Anxiety: Understanding Its Status and Insiders' Awareness and Attitudes. TESOL Quarterly, 47(2), 216-243.

24. Woodrow, L. (2006). Anxiety and speaking English as a second language. RELC Journal, 37(3), 308-328. 